\title{
The Influence of Demographic Development and Population Structure on the Demand for Public Passenger Transport
}

\author{
Vladimír Konečný ${ }^{1 *}$, Mária Brídziková ${ }^{1}$, Patrik Gažo ${ }^{1}$ and Štefánia Semanová ${ }^{1}$ \\ ${ }^{1}$ University of Žilina, Department of Road and Urban Transport, Univerzitná 1, 01026 Žilina, \\ Slovakia,Email:vladimir.konecny@fpedas.uniza.sk
}

*Corresponding Author: Vladimír Konečný

\begin{abstract}
A prerequisite for realizing the demand for public passenger transport is the existence of its potential which represents the population of a city, region or state. The number of inhabitants has a direct impact on the demand for transport. The paper deals with examining the relationship and dependence between the population demographic development and the demand for public passenger transport. Not only in Slovakia but also in Europe and in the world, the main problem is the ageing population. The changing age structure of the population changes requirements, demands and habits of transported population groups. A gradual increase in the holders of cards of a person with severe disability or a person with severe disability with accompaniment can be observed in Slovakia in recent years. This group of the population has also a very strong impact on the demand for public passenger transport. The dependence between individual variables is examined in the conditions of the Žilina self-governing region.
\end{abstract}

Keywords: Demand, public passenger transport, population age structure, demography, population ageing

\section{Introduction}

The paper points to the importance of examining the demand for public passenger transport in regard to the demographic development and population structure changes [1,2]. The population ageing is one of the major issues that challenge most countries and this is even expected to intensify in the upcoming decades. It is necessary to pay attention to this issue also in Slovakia [3,4].

Changes in population demographic distribution have also an impact on the demand for public passenger transport. The changing population age structure changes transport habits of the population [5-7]. This has a significant impact on the future functioning of the public passenger transport system having regard to adjustment of transport offer $[8,9]$. The population structure change in terms of the ageing population has also the impact on wheelchair accessibility in public passenger transport systems. 
The demand for public passenger transport is decreasing every year. The number of persons transported by public passenger transport decreased by $47.5 \%$ between 2004 and 2017.

\section{Data and Methods}

It is important to note that many factors have a significant impact on the comparison of individual countries and age structures of the population. This includes mainly social, political, economic and other factors that affect the birth rate, living standard in the country, social mentality of inhabitants as well as the overall population structure.

To compare population pyramids, France was selected due to the reason that a clearly visible difference in population age structure can be seen in the case of France compared to Slovakia.

\subsection{Analysis in the Slovak Republic}

In 2018, the population aged $35-39$ formed the top of the age pyramid in Slovakia (Fig. 1). This population age group represented $8.5 \%$ of the total population. A significantly low proportion was represented by the population aged $0-25$. This population group represented $26 \%$ of the total population. The low birth rate can be observed. The population aged 70 and over represented almost $10 \%$ of the total population of the country.

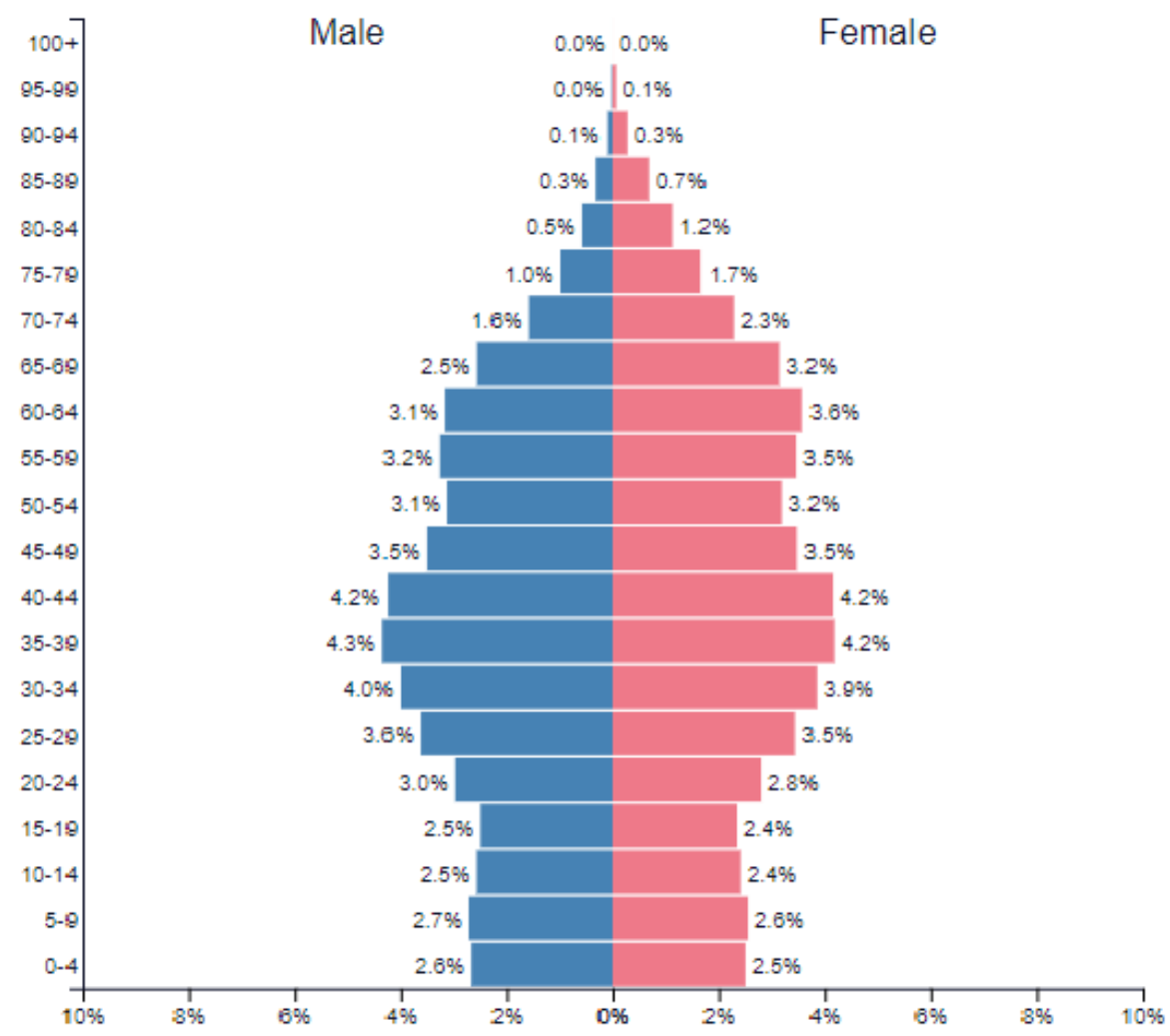

Fig. 1 Population pyramid in Slovakia in 2018. Source: [10]

The population development prognosis shows that the population will fall by about 300,000 inhabitants by 2040 (Fig. 2). The top of the age pyramid will move into the age range of $55-64$ 
years by 2040. The population pyramid will have a much narrower shape. The proportion of the population aged $0-25$ will decrease by $2 \%$ compared to 2018 . The population aged $35-39$, which formed the top of the pyramid in 2018 , will represent only $5 \%$ of the population in 2040 , resulting in a decrease of this age group by $3.5 \%$. A visible increase in the population aged 70 and over can be seen. This age group will represent the proportion of more than $16.5 \%$, showing an increase of more than $6.5 \%$ compared to 2018 .

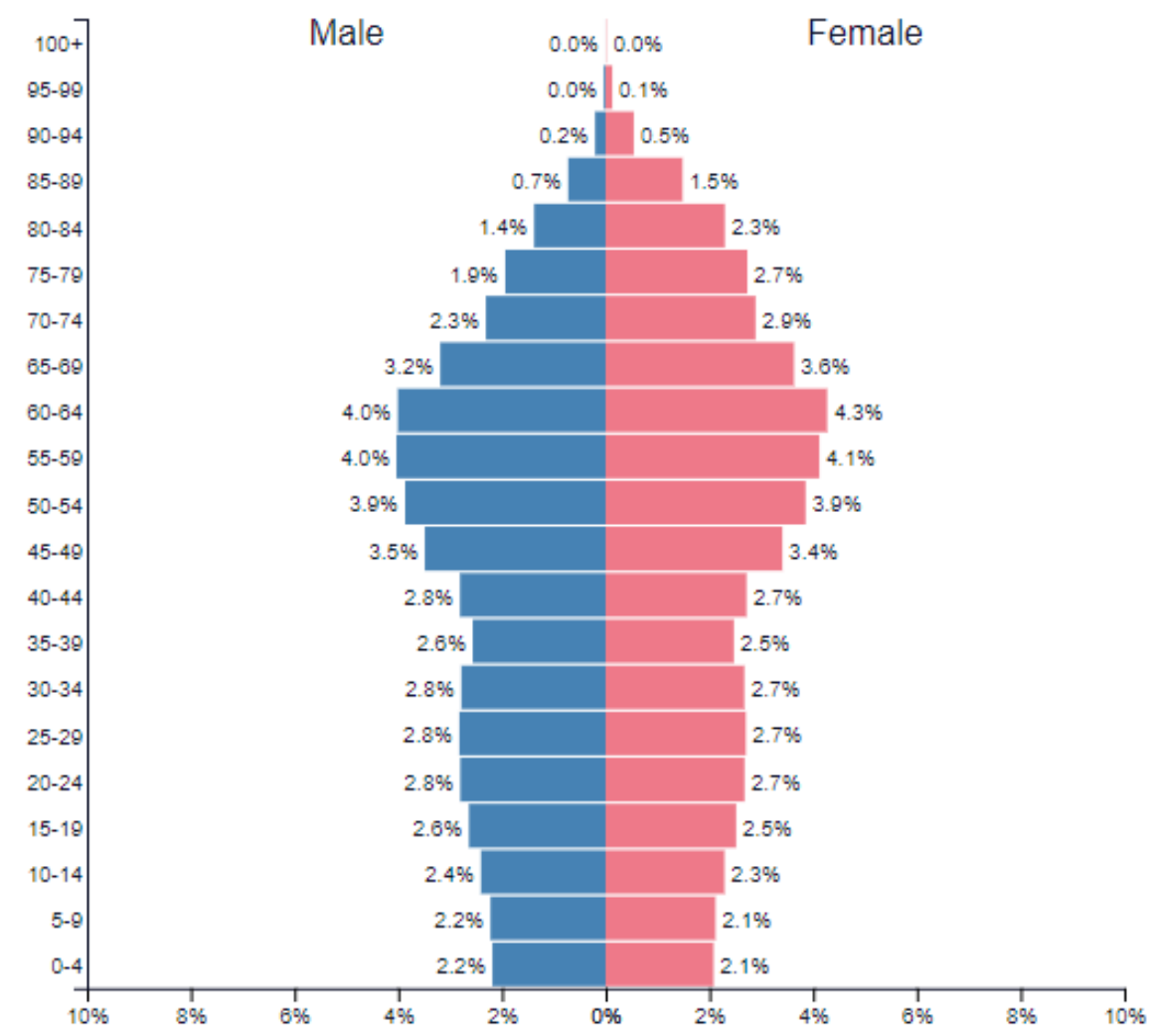

Fig. 2 Population pyramid in Slovakia in 2040. Source: [10]

\subsection{Analysis Abroad - France}

The age pyramid shape in 2018 was relatively balanced with minimal deviations (Fig. 3). The population aged 45 - 49 had the largest share, however, this did not represent a significant extreme. The birth rate was at a sustainable level. The proportion of age groups 70 and more gradually decreased. The population aged 70 and more represented $14 \%$ of the country's population and the population aged $0-25$ represented a $30 \%$ share. 


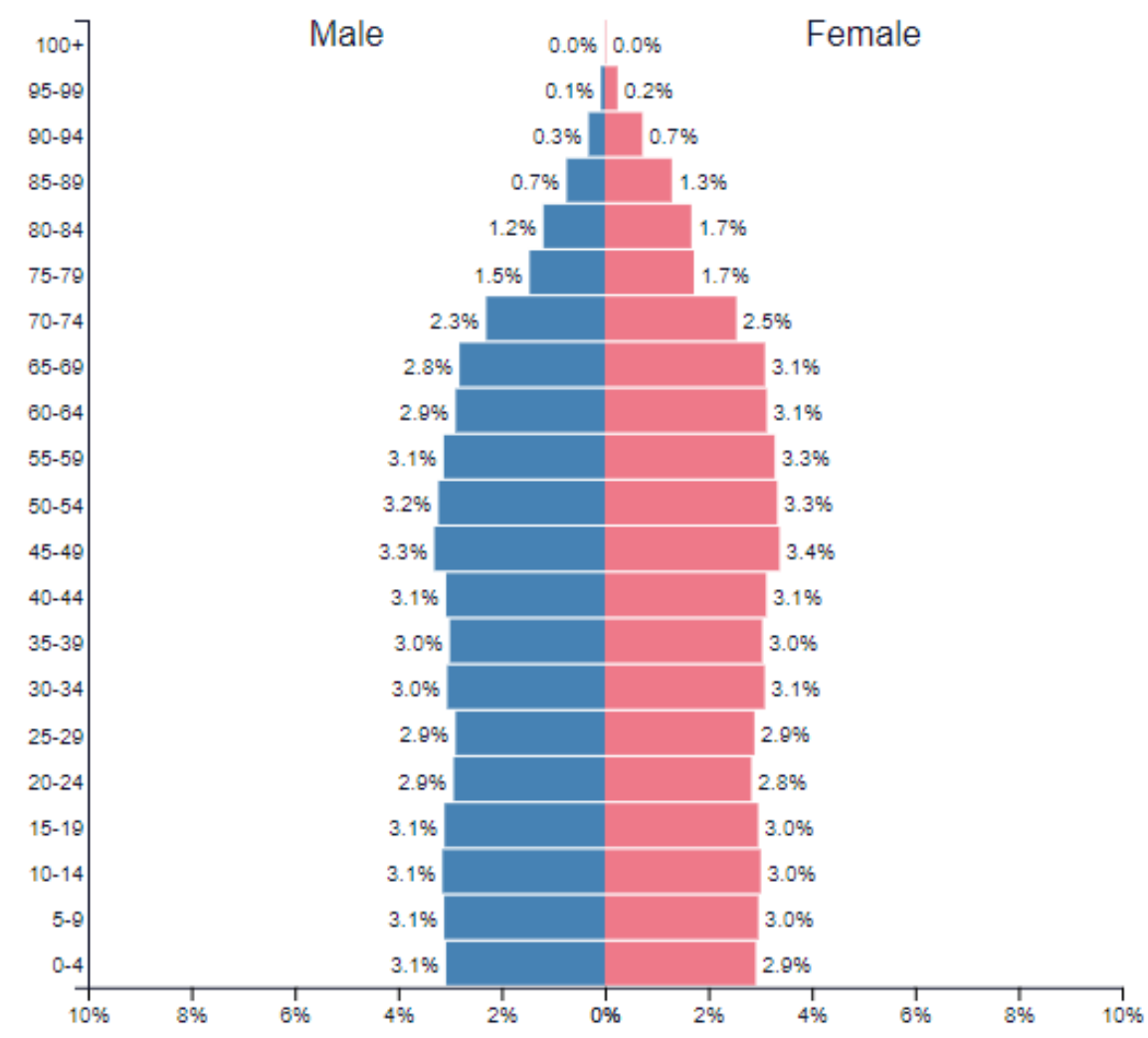

Fig. 3 Population pyramid in France in 2018. Source: [10]

The prognosis for 2040 shows that no significant changes in the demographic population distribution in France are expected (Fig. 4). The prognosis predicts an increase in the population by almost 5 million, however, the age pyramid shape will remain approximately preserved. The population pyramid will not contain extreme values thanks to uniform birth rate without significant changes over the years. In the case of the population aged $0-25$, a slight decrease to the level of 28 $\%$ is expected. Much more significant increase is expected for the population aged 70 and more. In spite of the population growth and approximately constant birth rate, a gradual ageing of the country's population can be observed.

By reducing the number of pupils, students and economically active population, the requirements for the offer of public passenger transport change during a day. Therefore, it is essential to examine modal split among individual age groups of the population, as it is done, for example, in Great Britain. In Great Britain, the government statistics analyses an indicator known as OADR - old age dependency ratio. The indicator expresses the ratio of people over 65 per every 1,000 inhabitants aged from 16 to 64 years. OADR is used to measure and demonstrate changes in the population structure [11]. 


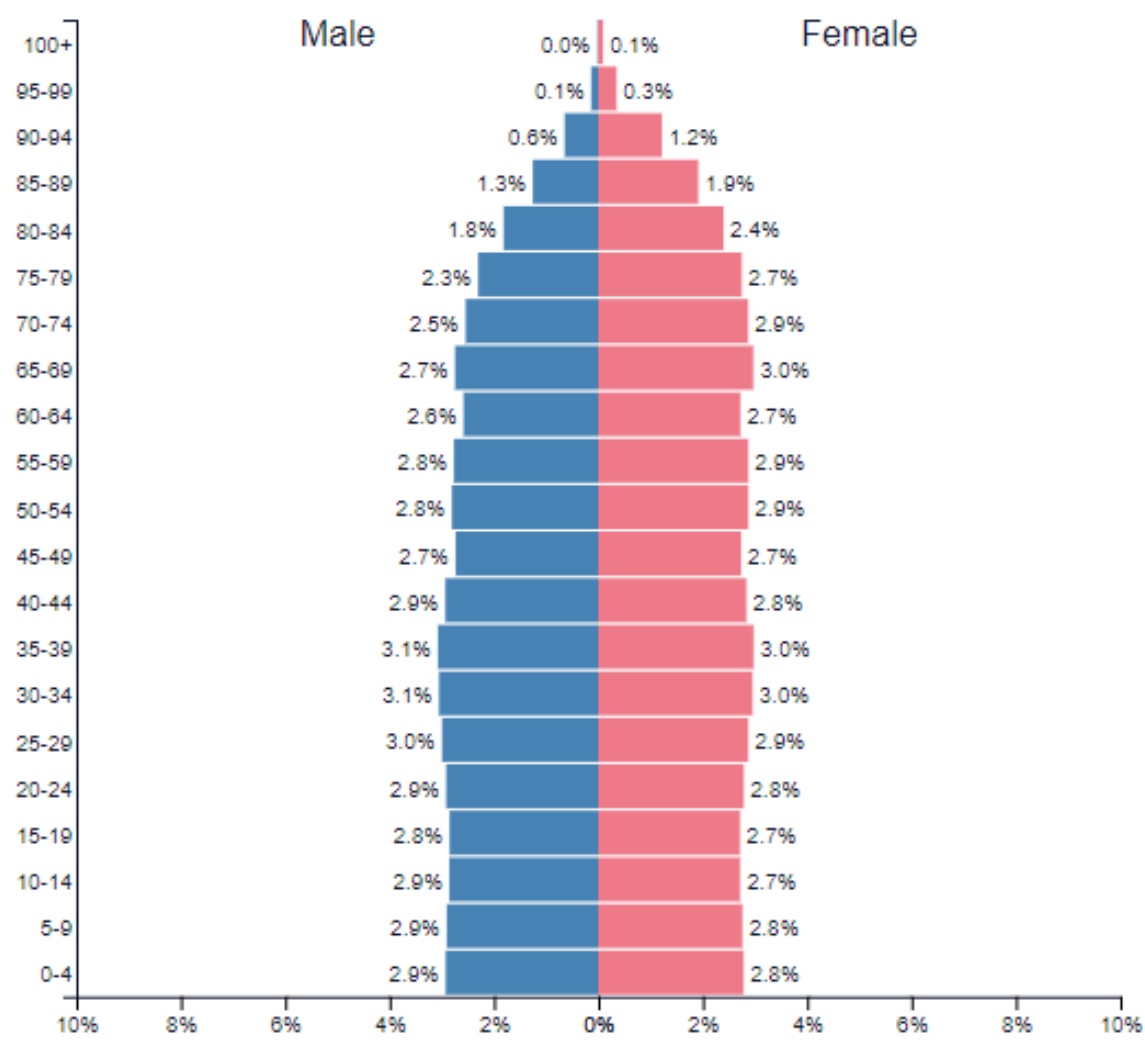

Fig. 4 Population pyramid in France in 2040. Source: [10]

\section{Results}

In order to simplify and streamline the system, it would be appropriate to unify the age limits used in tariffs of individual carriers in the future. Based on the analysis carried out, a case study for the Žilina self-governing region was elaborated.

\subsection{Proposal to Unify the Population Age Groups with the Tariffs of Carriers}

Given the demand for public passenger transport, the delimitation of age limits should be applied to the age groups used by carriers of public passenger transport in tariffs and tariffs conditions in the public passenger transport systems. The analysis carried out related to tariff conditions of carriers operating suburban bus transport provided based on public service contracts in each self-governing region in Slovakia as well as Železničná spoločnost' Slovensko, a.s. (hereinafter referred to as ZSSK) as a rail transport operator. Based on the most frequently occurring age groups, individual age limits of the population groups were determined. Based on this analysis, the population will be further divided in the following age groups:

- children from 0 to 5 years including,

- pupils from 6 to 14 years including,

- students from 15 to 25 years including,

- economically active population from 26 to 61 years including, 
- citizens from 62 to 69 years including,

- citizens aged 70 and over.

Table 1 Analysis of age groups of individual passengers in tariffs of carriers. Source: authors based on $[12,20]$

\begin{tabular}{|c|c|c|c|c|c|c|c|c|c|c|c|}
\hline & \multirow{2}{*}{\begin{tabular}{|c|}
$\begin{array}{c}\text { Population } \\
\text { group }\end{array}$ \\
$\begin{array}{c}\text { Self-governing } \\
\text { region }\end{array}$ \\
\end{tabular}} & \multicolumn{2}{|c|}{ Children } & \multicolumn{2}{|c|}{ Pupils } & \multicolumn{2}{|c|}{ Students } & \multicolumn{2}{|c|}{$\begin{array}{c}\text { Economically } \\
\text { active } \\
\text { population }\end{array}$} & \multicolumn{2}{|c|}{ Pensioners } \\
\hline & & $\begin{array}{l}\text { from } \\
\text { (incl.) }\end{array}$ & to & $\begin{array}{l}\text { from } \\
\text { (incl.) }\end{array}$ & to & $\begin{array}{l}\text { from } \\
\text { (incl.) }\end{array}$ & to & $\begin{array}{l}\text { from } \\
\text { (incl.) }\end{array}$ & to & $\begin{array}{c}\text { from } \\
\text { (incl. } \\
\quad \text { ) }\end{array}$ & to \\
\hline \multirow{8}{*}{ 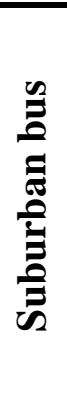 } & Banskobystrický & 0 & 3 & 3 & 15 & 15 & 26 & 26 & 70 & 70 & - \\
\hline & Bratislavský & 0 & 6 & 6 & 16 & 16 & 26 & 26 & $62^{1}$ & $62^{1}$ & - \\
\hline & Košický & 0 & 6 & 6 & 15 & 15 & 26 & 26 & 70 & 70 & - \\
\hline & Nitriansky & 0 & 6 & 6 & 15 & 15 & 26 & 26 & 70 & 70 & - \\
\hline & Prešovský & 0 & 6 & 6 & 15 & 15 & 26 & 26 & 70 & 70 & - \\
\hline & Trenčiansky & 0 & 6 & 6 & 15 & 15 & 26 & 26 & $70^{2}$ & $70^{2}$ & - \\
\hline & Trnavský & 0 & 6 & 6 & 15 & 15 & 26 & 26 & 70 & 70 & - \\
\hline & Žilinský & 0 & 6 & 6 & 15 & 15 & 26 & 26 & $70^{3}$ & $70^{3}$ & - \\
\hline ZSS & & 0 & 6 & 6 & 15 & 15 & 26 & 26 & $70^{4}$ & $70^{4}$ & - \\
\hline Mo & t frequent value & $\mathbf{0}$ & 6 & 6 & 15 & 15 & 26 & 26 & 70 & 70 & - \\
\hline \multicolumn{12}{|c|}{1 in the case of beneficiary of old-age, disability or service pension, the age limit is 60 years } \\
\hline \multicolumn{12}{|c|}{2 citizens over 62 years, who are beneficiary of old-age pension, on Saturdays, Sundays, public holidays, working days } \\
\hline \multicolumn{12}{|c|}{ from 10:00 to 12:00 and from 17:00 to 23:00 - holders of a transport card or MultiCARD county card } \\
\hline \multicolumn{12}{|c|}{3 fares for citizens aged 65 - 70 years on Saturdays, Sundays, public holidays, working day from 16:00 to 24:00 } \\
\hline \multicolumn{12}{|c|}{4 in the case of beneficiary of old-age, disability or service pension, the age limit is 62 years } \\
\hline
\end{tabular}

\subsection{Case Study in the Žilina Self-governing Region}

The case study is applied to the territory of the Žilina self-governing region (hereinafter referred to as ŽSK). The future demand for public passenger transport is estimated by using a regression analysis. Single-criterion regression functions based on the past population development in the relevant age group and the number of passengers carried within that age group were determined for individual passenger groups. The regression analysis included data from the period 2013 - 2018, i.e. a 6-year period (limited by the data obtained). The new independent variable representing the number of inhabitants in a given group in the forecast period is then added into the regression function and it is calculated how the dependent variable changes, i.e. the number of passengers carried for the given type of fare. The used prognosis of the population in ŽSK includes data for 2028 (a 10-year period) and 2035 (the highest available forecast). The prognosis was published by the Demographic Research Centre, INFOSAT [21]. However, it should be noted that these predictions are based only on purely mathematical-statistical calculations. 


\section{- Population group aged 0 - 15 years including}

The prognosis shows that the population will decrease by $10 \%$ in the following 10 years and it will decrease by $20 \%$ in 2035 compared to 2018. Based on the regression equation, the number of passengers aged $0-15$ years including will decrease by more than $77 \%$ by 2035 .

Regression function: $\quad \mathrm{Y}=13.428 \cdot \mathrm{X}-2,235$

Coefficient of determination (reliability equation): $\mathrm{R}^{2}=0.9422(94.22 \%)$

Table 2 Application of regression analysis for passenger group aged $0-15$ years including. Source: authors

\begin{tabular}{ccc}
\hline Year & Population & Number of passengers \\
\hline 2018 & 115,573 & $1,394,310$ \\
\hline 2028 & 104,234 & $1,397,419$ \\
\hline 2035 & 92,458 & 314,711 \\
\hline
\end{tabular}

\section{- Population group aged 16 - 25 years including}

The prognosis shows that the number of students aged $16-25$ years including will decrease by more than 8,500 inhabitants over 10 years, resulting in a $10 \%$ decrease. The decrease in the number of passengers represents $7.59 \%$. Between 2028 and 2035, the population of this age group is expected to increase by $3.2 \%$ and the number of passengers will increase by $3.27 \%$.

Regression function: $\quad \mathrm{Y}=99.469 \cdot \mathrm{X}-108,180$

Coefficient of determination (reliability equation): $\mathrm{R}^{2}=0.9905(99.05 \%)$

Table 3 Application of regression analysis for passenger group aged 16 - 25 years including.

Source: authors

\begin{tabular}{ccc}
\hline Year & Population & Number of passengers \\
\hline 2018 & 81,426 & $7,714,087$ \\
\hline 2028 & 72,757 & $7,128,886$ \\
\hline 2035 & 75,098 & $7,361,743$ \\
\hline
\end{tabular}

\section{- Population group aged 26 - 69 years including}

This population group is characterized by indirect linear dependence. The prognosis shows the decrease in the population by $1 \%$ by 2028 and $4 \%$ by 2035 compared to 2018. Based on the regression function, the number of passenger will increase by $13.5 \%$ by 2028 and $10 \%$ by 2035 compared to 2018. However, it should be noted that this effect is caused by mathematical dependencies. Only the relationship between the number of inhabitants and the number of 
passengers is examined while the number of passengers is also influenced by other various factors that were already mentioned in more detail in the paper.

Regression function: $\quad \mathrm{Y}=30.128 \cdot \mathrm{X}+50,148$

Coefficient of determination (reliability equation): $\mathrm{R}^{2}=0.9514(95.14 \%)$

Table 4 Application of regression analysis for passenger group aged 26 - 69 years including.

Source: authors

\begin{tabular}{ccc}
\hline Year & Population & Number of passengers \\
\hline 2018 & 427,880 & $11,306,356$ \\
\hline 2028 & 423,136 & $12,836,472$ \\
\hline 2035 & 410,361 & $12,449,832$ \\
\hline
\end{tabular}

\section{- Population group aged 70 years and over}

Based on the prognosis, the population aged 70 and over will increase by more than $45 \%$ by 2028 and $71.5 \%$ by 2035 compared to 2018 . The number of passengers will also increase. It will increase by $49 \%$ in 10 years and $75.16 \%$ by 2035 .

Regression function: $\quad \mathrm{Y}=17.543 \cdot \mathrm{X}+6,610.4$

Coefficient of determination (reliability equation): $\mathrm{R}^{2}=0.9952(99.52 \%)$

Table 5 Application of regression analysis for passenger group aged 70 years and over. Source: authors

\begin{tabular}{ccc}
\hline Year & Population & Number of passengers \\
\hline 2018 & 66,489 & $1,146,156$ \\
\hline 2028 & 96,840 & $1,705,475$ \\
\hline 2035 & 114,061 & $2,007,583$ \\
\hline
\end{tabular}

\section{Discussion}

For the future, it is important to pay attention to the development of the number of issued cards of a person with severe disability or a person with severe disability with accompaniment. The holders of such cards are also entitled to reduced fares in public passenger transport systems. Given that they travel for discount fares, financial costs to be borne by the ordering party (public authority) occur.

Furthermore, it is also very important to forecast the demographic population development as this development has an important impact on the functioning of society as well as the demand for public passenger transport. By population ageing, individual parts of the population are moving to higher age categories over time (e.g. a certain number of students move to the group of economically active population or a part of economically active population moves to the category of inhabitants aged $62-69$, etc.). This is also associated with changes in transport habits. The size and 
movement of the population between individual age groups is mainly influenced by fertility, mortality and population migration. In 2002, the Demographic Research Centre published the Prognosis of population development of the Slovak Republic till 2050. Fig. 5 shows the age structure change of the population in the SR between 2000 and 2017 and the prognosis of the population state in 2040 .
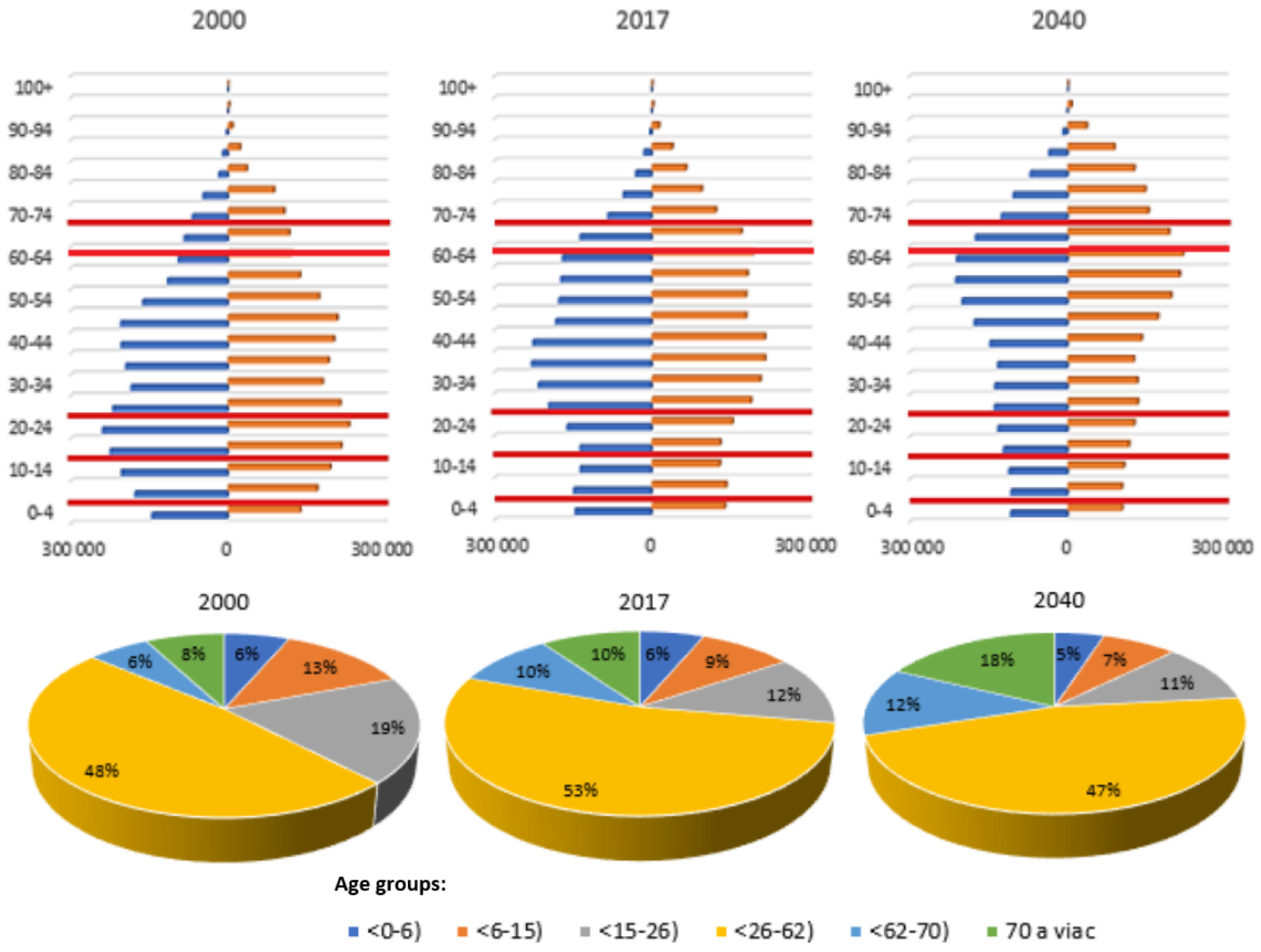

Fig. 5 Population age development in the SR. Source: authors based on [23]

\section{Conclusion}

The demographic structure of the population has a demonstrable impact on the demand for public passenger transport. The population represents the potential of the demand for transport services in public passenger transport systems. It is necessary to pay attention to the population demographic structure not only from the perspective of carriers but in particular from the side of public authorities as ordering parties in public service contracts.

The population ageing is a current and important topic. With gradual ageing of the population, the transport habits will change, too (demands and requirements for transport services will change). The number of passengers of the elderly age group is increasing and thus the overall demand for transport services changes. Their share in the total number of persons carried is gradually 
increasing. Also, the demand changes during a day and month, which results from transport habits of passengers. It is necessary to examine and developed further prognoses of the population development and to adjust the whole public passenger system to upcoming changes in order to make public transport attractive for passengers as well as sustainable for the future.

The prognoses of the population age development should be elaborated at regional level in order to be freely available either to public authorities or carriers. Practice from foreign countries may be used as an example. For instance, it would be appropriate to introduce an indicator that clearly defines the level of the population ageing and points to the changes in the population structure, following OADR indicator in Great Britain.

To simplify the whole system, it would be appropriate to unify the age limits used in the tariffs of individual carriers. Differences among tariffs and tariff conditions of carriers occur especially in the case of seniors. Another important step is to re-evaluate systems of fare discounts offered by individual carriers or its unification, if possible. This would result in removing the barrier between individual kinds of public passenger transport and also this represents an essential step towards establishing integrated transport systems.

Special attention should be also drawn to groups of passengers that are the holders of cards of a person with severe disability or a person with severe disability with accompaniment. The number of these cards is increasing significantly every year. The number of passengers entitled to discount fares based on these cards also increases, but not at such a rapid pace as in the case of the number of the issued cards. Therefore, the question is: "What is the purpose of issuing such cards as also other advantages are associated with their ownership?" It would be appropriate to reconsider the conditions for obtaining these cards in the Slovak Republic.

\section{Acknowledgments}

This paper has been developed under support of project: MŠVVŠ SR VEGA No. 1/0566/18 KONEČNÝ, V.: Research on the impact of supply and quality of transport services on the competitiveness and sustainability of demand for public transport.

\section{References}

[1] Paulley, N., Balcombe, R., Mackett, R., Titheridge, H., Preston, J., Wardman, M., Shires, J., $\&$ White, P. (2006). The demnad for public transport: The effects of fares, quality of service, income and car ownership. Transport Policy 13(4), 295-306. DOI: 10.1016/j.tranpol.2005.12.004.

[2] Metz, D. (2012). Demographic determinants of daily travel demand. Transport Policy 21, 2025. DOI: 10.1016/j.tranpol.2012.01.007. 
[3] Gnap, J. \& Konečný, V., (2008). The impact of a demographic trend on the demand for scheduled bus transport in the Slovak Republic. Komunikacie 10(2), 55-59. ISSN:13354205.

[4] Konečný, V., Berežný, R., Petro, F. \& Trnovcová, M. (2017). Research of demand for bus transport and transport habitsof high school students in Žilina region. LOGI-Scientific Journal transport and Logistics 8(2), 47-58. DOI: 10.1515/logi-2017-0016.

[5] Metz, D. (2010). Transport policy for an ageing population. Transport Rewievs 23(4), 375386. DOI: $10.1080 / 0144164032000048573$.

[6] Alsnih, R. \& Hensher, D. A. (2003). The mobility and accessibility expectations of seniors in an aging population. Transport Policy 37(10), 903-916. DOI: 10.1016/S0965-8564(03)000739.

[7] Veterník, M. \& Gogola, M. (2017). Examining of correlation between demographic development of population and their travel behaviour. Procedie Engineering 192, 929-934. DOI: 10.1016/j.proeng.2017.06.160.

[8] Bowering, T. (2019). Ageing, Mobility and the City: Objects, Infrastructures and Practices in Everyday Assemblages of Civic Spaces in East London. Journal of Population Ageing 12(2), 151-177. DOI: 10.1007/s 12062-019-9240-3.

[9] Wong, R. C. P., Szeto, W. Y., Yang, L. C., Li, Y. C. \& Wong, S. C. (2017). Elderly users' level of satisfaction with public transport services in a high-density and transit-oriented city. Journal of Transport \& Health 7, 209-217. DOI: 10.1016/j.jth.2017.10.004.

[10] Website for displaying and forecasting population pyramids $<$ https://www.populationpyramid.net/>

[11] Demographic trends: How will an aging population affect transport planning and urban regeneration? Available at: https://www.mayerbrown.co.uk/keep-up-todate/blog/posts/demographic-trends-how-will-an-aging-population-affect-transport-planningand-urban-regeneration/

[12] Tariff conditions determined by Banská Bystrica self-governing region for suburban bus transport provided based on the public service contract. Available at: < https://www.vucbb.sk/Portals/0/Files/tarifne-podmienky- bbsk-1-6-2012.pdf>.

[13] Transport regulation of Integrated Transport system in Bratislava county, valid from 1.10.2018. Available at: 〈https://www.idsbk.sk/ download/B20180927T000000194.pdf〉. 
[14] Tariff conditions in suburban regular bus transport provided based on the public service contract in Košice self-governing region. Available at: <https://web.vucke.sk/files/doprava/ priloha-c-2a-k-zmluve- 2013-tarifa-eurobus.pdf>.

[15] Tariff conditions in suburban regular bus transport provided based on the public service contract concluded with the company of ARRIVA Nitra a. s. Available at: < www.arrivanitra.sk/res/data/018/002201.pdf>.

[16] Tariff conditions in suburban regular bus transport provided based on the public service contract in Prešov self-governing region. Available at. Dostupné na internete: <https://www.po-kraj.sk/sk/samosprava/urad/odbor- dopravy/cestovne-poriadky/>.

[17] Tariff of suburban bus transport, SAD Trenčín, a. s. company. Valid from 01.09.2018. Available at: < https://www.sadtn.sk/files/download/tarifa_pal_01092018. pdf?1540484281>.

[18] Fares in TTSK č. 1/2011. Available at: < http://www.sadtrnava. sk/data/cenniky/cenovy_vymer_vuc_novy.pdf>.

[19] Tariff of suburban bus transport carrier for carriage of passengers and baggage. SAD Žilina a.s. company. Available at: < https://www.sadza.sk/files/tarifa-primestska-doprava. pdf?1540484741>.

[20] Transport regulation of Železničnej spoločnosti Slovensko, a. s. company. Valid from 15.06.2015. Available at: <http://www.slovakrail.sk/uploads/tx_main/201 8/01/23/PP_ZSSK_vydanie_7_so_zaprac_zmenou_5_od_2018-02-01_-_final.pdf>

[21] Demographic Research Centre, INFOSTAT. Population Prognosis in the SR 2013-2015 self-governing regions. Available at: < http://www.infostat.sk/vdc/sk/index.php?option=c om_content $\&$ view=category $\&$ layout=blog $\& \mathrm{id}=12 \&$ Itemid $=56>$.

[22] Kubikova, S., Kalasova, A. \& Cernicky, L. (2014). Microscopic Simulation of Optimal Use of Communication Network, Telematics - Support for Transport, Communications in Computer and Information Science J. Mikulski, ed., pp. 414-423, Berlin: Springer-Verlag Berlin.

[23] Demographic Research Centre, INFOSTAT. Prognosis of population development in the SR till 2050. Edition: Acts, Bratislava, November 2002. 35-2002-A/9 